\author{
Joanna Deugosz
}

\title{
The Principle of Proportionality in European Union Law as a Prerequisite for Penalization
}

\section{Introduction}

The issue underlying the functioning of the European Union, in the achievement of its objectives and performance of tasks, is the observance of the legal principles that govern decision-making processes and common strategic objectives, and which are applicable when establishing European Union legislation and transposing it into national law1, including in the area of criminal law. One of these principles is the principle of proportionality which, due to its complexity and significance for the processes of establishing and applying the law, requires detailed and separate discussion.

\section{The concept of proportionality in the EU legal order}

The principle of proportionality, which is one of the few principles expressed explicitly in the European Union acts, ${ }^{2}$ is widely applied in the EU legal order and is therefore one of the fundamental principles of the EU system ${ }^{3}$. Its formation proceeded on two planes: normative and case-law.

As regards the primary law of the European Union, the principle of proportionality acquired the status of a treaty when the Treaty of Maastricht entered into force (see

1 M. Witkowska, Zasady funkcjonowania Unii Europejskiej, Warszawa 2008, p. 178.

2 See Article 5(4) of the Treaty on European Union (hereinafter: TEU): "Under the principle of proportionality, the content and form of Union action shall not exceed what is necessary to achieve the objectives of the Treaties. The institutions of the Union shall apply the principle of proportionality as laid down in the Protocol on the application of the principles of subsidiarity and proportionality."

3 J. Maliszewska-Nienartowicz, Rozwoój zasady proporcjonalności w europejskim prawie wspólnotowym, „Studia Europejskie” 2006, no. 1, p. 59; W. Szpringer, Subsydiarność jako zasada ustrojowa w państwie federalnym - cztonku Unii Europejskiej (na przyktadzie RFN), in Subsydiarność, ed.

D. Milczarek Warszawa 1998, p. 116. 
the then Article $3 \mathrm{~b} \S 3$ of the Treaty), but it should be noted that its standardisation in Part I of the EC Treaty ("Principles") means that it has been raised to the rank of a fundamental principle that underpins the legal and institutional order of the European Communities ${ }^{4}$. After the Treaty of Amsterdam entered into force, which did not introduce any substantial changes to this regulation, apart from revising the numbering of individual provisions, the normative basis for the functioning of the principle of proportionality was contained in Article 5(3) of the Treaty establishing the European Community (TEC), providing that: "[any] action by the Community shall not go beyond what is necessary to achieve the objectives of this Treaty," detailing the criteria for applying this principle, as well as the practical issues related to its application, contained in 'Protocol on the application of the principles of proportionality and subsidiarity' attached to the Treaty. ${ }^{5}$

Applicable de lege lata, the Treaty of Lisbon contains many references to the principle of proportionality. It should be noted that in relation to the previous legal situation, it does not introduce any significant changes in this respect. The normative basis for the application of the principle is Article 5 of the new TEU (replacing Article 5 of the TEC), which provides in $\S 4$ : "under the principle of proportionality, the content and form of Union action shall not exceed what is necessary to achieve the objectives of the Treaties. The institutions of the Union shall apply the principle of proportionality as laid down in the Protocol on the application of the principles of subsidiarity and proportionality." Interpretation of this provision allows the assertion that the principle of proportionality has not fundamentally changed. The modifications introduced by this regulation are limited to a number of technical amendments, i.e.: the principle in question no longer concerns only the "Community action" (see Article $5 \S 3$ TEC), but extends to the "content and form of Union action". Moreover, this general regulation includes a direct reference annexed to the Treaty and thus has the same legal force ${ }^{6}$ as the new ${ }^{7}$ Protocol on the application of the

4 J. Maliszewska-Nienartowicz, op. cit., p. 66 and references therein.

5 It should be noted at the outset that the treaty wording of this principle, despite the extensive ECJ case law already in place at the time of adoption of the Treaty, takes account only of the requirement of necessity, omitting the justification of the measure in relation to the achieved objective and proportionality. With regard to the assessment of this fact, see ibidem, p. 68 and references therein.

6 D. Milczarek, Subsydiarność-próba bilansu, in Subsydiarnośc, op. cit., p. 327.

7 The Treaty of Lisbon provides that the existing Protocol on the application of the principles of subsidiarity and proportionality, annexed to the EC Treaty, is repealed and replaced by a new protocol with the same title. What is new is the emphasis on the particular importance of the European Commission, which, before submitting any proposal for a legislative act, has been committed to conduct wide-ranging consultations, taking into account, in appropriate cases, the regional and local dimension of the actions carried out (Article 2 of the Protocol). In practice, this means that the Commission will have to take into account the principle of proportionality already at the preparatory stage, i.e. before the formal opening of the legislative process. Furthermore, the Protocol upholds the requirement to justify draft leg- 
principles of subsidiarity and proportionality', which contains a set of rules, precise criteria and the practical aspects concerning the application of these two principles, ${ }^{8}$ including the provision that each institution, when exercising the powers conferred on it, shall ensure constant respect for the principle of proportionality, as defined in Article 5 TEU. The 'Protocol' also lays down the requirement that each Community legislative act should state the reasons why the principle of proportionality was taken into consideration at the time of its creation.

It is worth noting, however, that, contrary to the case-law of the ECJ, the general provisions of the Treaty and the provisions of the Protocolonly cover the European Union's action and, in particular, the exercise of its powers, without taking into account the functions of the principle in question which relate to actions taken by Member States in the application of EU law. ${ }^{9}$ It should be stressed, however, that the inclusion of this principle in the Treaties, followed by the indication in the Protocol of criteria allowing the EU institutions to apply it precisely, is of constitutive significance and made it a Treaty principle of general scope, since until then it was applicable only in the field of soft law. Since the Treaty of Maastricht entered into force, it has had priority over the secondary law applied by EU institutions, and moreover has had permanent status, since any change would require revision of the Treaty. This automatically gives the Court of Justice the power to verify the conformity of EU legislation with respect to this principle. ${ }^{10}$

In conclusion, it can be assumed that the function of the principle of proportionality is to control the manner in which the European Union exercises its powers, both in relation to Member States and individuals, and to assess the activities of those states. The overriding aim dictated by the desire to safeguard the interests of Member States and individuals is to prevent the EU from interfering in the freedom of those entities. ${ }^{11}$

islative acts with respect to the principles of subsidiarity and proportionality (Article 5 of the Protocol), while extending this obligation to include in each justification a detailed statement making it possible to assess compliance with these principles.

8 See $\S 2$ of the preamble of the Protocol. It can therefore be concluded from the content of the Protocol that its provisions do not relate to the substance or scope of the principle in question, but merely contain procedural rules intended to facilitate its implementation.

9 For more on this subject, see J. Maliszewska-Nienartowicz, Sqdowe stosowanie zasady proporcjonalności, "Europejski Przegląd Sądowy" 2009, no. 1, p. 11 et seq.

10 See, e.g., the ECJ rulings in the following cases: Hauer v. Land Rheinland-Pfalz, 44/70, p. 3727; Bela-Mühle v. Grows Farm, 114/76, p. 1211; The Queen, ex parte E.D. Eं F. Man (Sugar) Ltd v. Intervention Board for Agricultural, 181/84, p. 2889; The Queen v. Minister of Agriculture, Fisheries and Food and Secretary of State for Health ex parte Fedesa and others, 331/88, p. 4023.

11 J. Maliszewska-Nienartowicz, Rozwój zasady..., op. cit., p. 66 and references therein; eadem, Zasada proporcjonalności w prawie Wspólnot Europejskich, Torun 2007, p. 252. For the sake of clarity, it is worth mentioning two important issues. Firstly, the substantial change introduced by the Treaty of Lisbon into Article 296 TFEU (ex Article 253 TEC) by adding the sentence stating that "where the Treaties do not specify the type of act to be adopted, the institutions shall select it on a case-by-case basis, in compliance with the applicable procedures and 
It follows from the above, however, that neither the Treaty's general legislation nor the Protocol include precise criteriafor the principle in question. Its determination should therefore be based on the ECJ case law.

In elaborating on the issue of the principle of proportionality in the case law of the European Court of Justice, it must be noted that, in terms of chronology, this principle appeared in European law (then: the Community) in the rulings of the European Court of Justice in the 1950s. ${ }^{12}$ Initially, however, it was not considered to be a general principle of law, and it only acquired the status of a principle for the overall assessment of the Community activities in an ECJ judgment of 1970, where the Court, speaking of it in the context of protection of fundamental rights, stated that "the freedom of action of individuals should not be limited beyond what is required for public interest purposes." ${ }^{13}$ In practice, this meant introducing the requirement of proportionality to the Community's interference in the rights of the individual. ${ }^{14}$ Under the successive judgements of the Court, the scope of this principle has been gradually extended to other manifestations of action taken by the Community institutions and, consequently, to the actions of Member States. In 1983, the Court in its subsequent ruling introduced a control mechanism for these actions in the light of the principle of proportionality, stating: "in order to determine whether a provision of Community law complies with the principle of proportionality, it must be determined, first, whether the measures which are envisaged for achieving the objective correspond to the significance of the objective, and secondly, whether they are necessary to achieve it." 15 It can be inferred form this word-

with the principle of proportionality." Secondly, the provisions of the Charter of Fundamental Rights of the European Union (hereinafter: ChFR EU), of which in the context of the application of the principle of proportionality the provisions of Article 49 (principles of legality and proportionality of criminal offences and penalties), and Article 52 (scope of guaranteed rights) of the ChFR EU seem particularly important.

12 See, e.g., the ECJ rulings in Fédération Charbonnière de Belgique v. High Authority, 8/55, p. 292; Compagnie des Hauts Fourneaux de Chasse v. High Authority, 15/57, p. 211. For more on this subject, see e.g. J. Maliszewska-Nienartowicz, Sqdowe..., op. cit., p. 60 et seq.

13 See the ECJ ruling in Internationale Handelsgesselschaft GmBH v. Einfuhr- und Vorratstelle für Getreide und Futtermittel, 11/70, p.1125; M. Witkowska, op. cit., p.178; A. Wyrozumska, Państwa cztonkorwskie a Unia Europejska, in Prawo Unii Europejskiej. Zagadnienia systemowe. Prawo materialne i polityki, ed. J. Barcz, Warszawa 2006, p. 322.

14 Cf. J. Maliszewska-Nienartowicz, Rozwój zasady..., op. cit., p. 61; A. Wyrozumska, op. cit., p. 322. See also J. Rivers, Proportionality and discretion in international and European law, in Transnational Constitutionalism. International and European Models, ed. N. Tsagourias, Cambridge 2009, p. 110 et seq.

15 See the ECJ judgement in the case Fromançais S.A. v. Fonds d'orientation et de régularisation des marchés agricoles (FORMA), 66/82, p. 395. This mechanism was also applied in later judgements of the Court, see e.g. Office belge de l'économie et de l'agriculture (OBEA) v. SA Nicolas Corman et fils, 125/83, p. 3039; Commission v. Federal Republic of Germany, 116/82, p. 2519. For more on this issue, see J. Maliszewska-Nienartowicz, Rozwój zasady..., op. cit., p. 62 et seq. 
ing that the principle of proportionality imposes certain restrictions on law-making and enforcing authorities. These constraints consist in requiring a certain balance between the scope and nature of the activities they undertake, and the intended purpose which they are to serve. ${ }^{16}$ In its rulings, therefore, the Court pointed out the need to use the proportionality test. It consists in analysing the compatibility of a given legal measure with the principle in question using a three-tiered mechanism: firstly, it must be stated that the measure is appropriate for achieving a given objective, ${ }^{17}$ then that it is necessary for its achievement, ${ }^{18}$ and that it is commensurate. ${ }^{19}$

The concept of proportionality therefore allows for two conclusions: the EU acts, and the actions taken on their basis, must be appropriate and necessary for achieving the objectives pursued by the regulation, and proportionate to the adverse consequences. On the other hand, if there are several appropriate measures, those that are the least invasive and burdensome for the Member States' freedom of action must be chosen. ${ }^{20}$

Thus, the principle of proportionality prohibits taking authoritative actions beyond necessity. The literature emphasizes that it serves both to assess the implementation of the provisions of EU law (i.e. legislative and administrative measures taken by the European institutions), ${ }^{21}$ as well as measures taken by Member States. In the latter case, it serves to check the compliance with the principle of proportionality of actions taken by Member States, or measures adopted by them, that either limit the rights and freedoms arising from EU primary law, or concern the interpretation of EU law by national

16 J. Maliszewska-Nienartowicz, Rozwój zasady..., op. cit., p. 63; A. Witkowska, op. cit., p. 178.

17 This criterion refers to the relationship between the measure used and the intended purpose, which must be justified in the light of Community law. The measure applied must be appropriate to achieve the objective, while the least possibly intrusive in the freedom of action of a Member State. For more on the subject, see J. Maliszewska-Nienartowicz, Zasada proporcjonalności w prawie Wspólnot Europejskich - kryteria i zakres kontroli dokonywanej przez Trybunat Sprawiedliwości, in Zasady ogólne prawa wspólnotowego, ed. C. Mik, Toruń 2007, p. 256 et seq.

18 The measure used must be necessary for the particular situation, i.e. not going beyond what is necessary to achieve the objectives. It is therefore necessary to examine whether there is already a measure less intrusive to the freedom of action, e.g. less stringent provision. For more on the subject, see J. Maliszewska-Nienartowicz, Zasada proporcjonalności w prawie Wspólnot Europejskich - kryteria..., op. cit., p. 258 et seq. These criteria were formulated by the ECJ in Schräder v. Hauptzollamt in Gronau, 265/87, p. 2237. See also the ECJ ruling in The Queen $v$. Minister of Agriculture, Fisheries and Food and Secretary of State for Health ex parte Fedesa and others, 331/88, p. 4023; N. Emiliou, The Principle of Proportionality in European Law, LondonThe Hague - Boston 1996, p. 191 et seq.

19 I.e. proportionate to the adverse effects or restrictions imposed on the individual. This is known as proportionality in the strict sense. For more on the topic, see J. Maliszewska-Nienartowicz, Zasada proporcjonalności w prawie Wspólnot Europejskich-kryteria..., op. cit., p. 261 et seq.

20 Cf. the ECJ ruling in Schräder v. Hauptzollamt in Gronau, 265/87, p. 2237.

21 See J. Maliszewska-Nienartowicz, Sadowe..., op. cit., p. 11 et seq.; eadem, Zasada proporcjonalności w prawie Wspólnot Europejskich, op. cit., p. 153 et seq. 
authorities when they apply it. ${ }^{22}$ This supervision may also relate to measures taken by Member States to implement EU law, as well as sanctions imposed by the authorities of the Member States for violation of this law, which are required to be effective, proportionate and dissuasive. ${ }^{23}$ At the same time, it should be emphasized that checking if national measures comply with the principle of proportionality may be carried out by both the $\mathrm{ETS}^{24}$ and - as a result of the ECJ decision - by national courts. ${ }^{25}$ However, some authors point out that the Court does not uniformly apply the principle in question, depending on the subject matter of the case, which may lead to the conclusion that it is a rather flexible means of judicial review, with the $\mathrm{ECJ}^{26}$ adopting substantially different standards for assessing the compatibility of legal acts with that principle. ${ }^{27}$

\section{The principle of proportionality in the criminal law of the European Union}

Although the principle of proportionality is one of the basic principles functioning in the national legal systems of the EU Member States, ${ }^{28}$ it is not often analysed in the context of European criminal law. This is primarily due to the disputed competence of the EU legislator with regard to establishing standards of criminal law. ${ }^{29} \mathrm{With}$ the gradual extension of the European Union's legitimacy to the area of criminal law, it is also becoming necessary to apply the basic norms and principles of EU law to this area. This section of the paper will therefore focus on discussing this aspect of the principle of proportionality.

22 See, e.g., the ECJ rulings in Tanja Kreil v. Niemcy, 285/98, p. 66; Cassis de Dijon, 120/78, p. 649. For more on this subject, see A. Wyrozumska, op. cit., p. 324 et seq.

23 J. Maliszewska-Nienartowicz, Rozwój zasady..., op. cit. p. 62; eadem, Saqowe..., op. cit., p. 13 et seq.; eadem, Zasada proporcjonalności w prawie Wspólnot Europejskich, op. cit., pp. 164 et seq.; A. Wyrozumska, op. cit., p. 322 et seq.

24 E.g. in H. Franzén, 189/95, p. 5909.

25 E.g. in Questore di Verona v. Diego Zenatti, 67/98, p. 7289. On the assessment of the possibility of adoption of these two solutions, see J. Maliszewska-Nienartowicz, Sadowe..., op. cit., p. 14 et seq.

26 A. Frąckowiak-Adamska, Zasada proporcjonalności jako grwarancja swobód rynku wewnętrznego Wspólnoty Europejskiej, Warszawa 2009, p. 32 et seq.; J. Maliszewska-Nienartowicz, Rozwoój zasady..., op. cit., p. 64 et seq.; eadem, Saqdowe..., op. cit., p. 16 et seq.

27 For more on this topic, see A. Frąckowiak-Adamska, Podwójne zasady badania proporcjonalności przez Trybunat Sprawiedliwości, in Zasady ogólne..., op. cit., p. 271 et seq.

28 Cf., inter alia, Article 42 section 1 of the Constitution of the Republic of Poland; Article 103 section 2 of the Constitution of the Federal Republic of Germany (Grundgesetz).

29 In this issue cf., inter alia: J. Piskorski, Legitymizacja prawa karnego Unii Europejskiej, Poznań 2013; M. Szwarc-Kuczer, Kompetencje Unii Europejskiej w dziedzinie harmonizacji prawa karnego materialnego, Warszawa 2011. 


\section{The concepts of proportionality}

As regards European criminal law, the concept of proportionality appears in many contexts. It can be found in the extensive ECJ case law discussed above, the Charter of Fundamental Rights (see. e.g. Article 49(3) ChFR EU), as well as many acts of the Community's secondary legislation, which often contain the wording whereby "sanctions (also: penalties or measures) [which] shall be effective, proportionate and dissuasive" 30 must be envisaged. This differentiation of the normative bases of the analysed principle allows us to conclude that proportionality in EU law is not a homogeneous notion. This view is also reflected in a doctrine in which two concepts of interpretation of this principle are distinguished. ${ }^{31}$

The first of these, known as retrospective proportionality, refers to the principle of proportionality in criminal law. Its essence is the assumption that the severity of the penalty must be commensurate with the seriousness of the offence, thus indicating that it is derived from the guaranteed function of criminal law. ${ }^{32}$ With the retrospectiveness of proportionality, the basis for the penalty is the fact that the act was committed by the perpetrator in the past. ${ }^{33}$ Because this criminal approach to proportionality focuses on a certain degree of dependence between the the seriousness of the offence and the severity of the penalty imposed for committing it, it is desirable to formulate criteria on the basis of which which the required degree of correlation can be estimated. In criminal law, it is assumed that this function has two main components: the degree of fault of the perpetrator and the degree of social harm of the offence. ${ }^{34}$

The second concept of proportionality relates to proportionality in the context of administrative law, which was broadly discussed in the first part of this study. In this context, the principle is expressed in the fact that all the measures taken (understood as regulations prohibiting specific conduct and providing specific sanctions for infringing

30 See e.g. Article 58 § 1 of the Directive of the European Parliament and of the Council 2015/849 of 5 May 2015 on the prevention of the use of the financial system for the purposes of money laundering or terrorist financing (Official Journal of the European Union of 5 June 2015, L 141 et seq) or Article $2 \S 1$ of the Convention of 26 July 1995 on the protection of the financial interests of the European Communities (Official Journal of 27 November 1995, C 316 p. 48 et seq.).

31 See, e.g., P. Asp, Two notions of Proportionality, in Materials from the $22^{\text {nd }}$ IVR Word Congress, p. 1, www.crimpol.eu/?p=200 [access: 12.02.2017]; N. Jareborg, Criminalization as Last Resort (Ultima Ratio), "Ohio State Journal of Criminal Law” 2004, no. 2, pp. 529, 532 et seq.

32 With regard to the principle of proportionality in criminal law, see e.g. M. Królikowski, Sprawiedliwośc karania w spoteczeństwach liberalnych. Zasada proporcjonalności, Warszawa 2005, p. 209 et seq.

33 See the ECJ rulings in the cases: Criminal proceedings v. Messner, 265/88, p. 4209; Skanavi, 193/94, p. 929.

34 See also Article $53 \S 1$ of the Polish Criminal Code (hereinafter: PCC). 
these prohibitions) must be proportionate to the objective to be achieved. This approach to proportionality defines the relationship between the measures taken and the objectives pursued, taking into account three essential elements, namely: the appropriateness, necessity and proportionality (sensu stricto) of the measures taken. Contrary to the principle of proportionality in criminal law, in this case one can speak of potential proportionality, since it concerns the relationship between certain measures and the objectives to be achieved in the future. ${ }^{35}$

Since the principle of potential proportionality - unlike the principle of retrospective proportionality - is updated not only with respect to the determination of the commensurability of the offence, but also with regard to many other aspects, the question arises of whether - when analysing the compliance of sanctions provided for by EU law with the principle of proportionality - the principle of retrospective proportionality, the principle of potential proportionality or both principles should be applied together. ${ }^{36}$ This problem also implies the existence of a relationship between both these principles.

An aspect that links these two concepts of proportionality seems to be a correlation with the issue of determining the adequacy of sanction severity. However, a cursory analysis suggests that both concepts refer to the issue of the proportionality of sanctions from two completely different perspectives. In accordance with the principle of potential proportionality, the sanction must be commensurate with the objective to be achieved. On the other hand, the implementation of the principle of proportionality in criminal law involves the imposition of a penalty proportional to the gravity of the offence already committed.

The purposes behind the implementation of this principle are also fundamentally different. In administrative law, its implementation is primarily a matter of establishing the objective to be achieved by applying a specific measure. Then it must be determined whether the measure is appropriate, necessary and proportionate to that objective. On the other hand, in criminal law, this objective is primarily preventive, consisting in the elimination of certain types of behaviour that are considered forbidden under penalty. These arguments could therefore lead to the conclusion that there are no major points of contact between the two concepts.

In the literature, however, there are views indicating a certain link between these two principles in the context in question. Asp recognizes it in relation to two elements of the principle of proportionality in the administrative-legal sense. Firstly, it is a condition of the need for a measure in relation to the objective to be achieved through its application. According to Asp, in the fact that the adoption of the requisite necessity is determined

35 See P. Asp, op. cit., p. 3; N. Jareborg, op. cit., pp. 529, 532.

36 An example of cumulative treatment of both principles by the ECJ is the judgement in Buitoni v. Fonds d'orientation et de régularisation des marchés agricoles (FORMA), 122/78, p. 2 et seq. 
by the assessment of the measure as the least intrusive and cumbersome, one can see a certain analogy to the criminal law concept of proportionality, which consists in assessing the relationship between the seriousness of the offence committed and the severity of the penalty for committing it, based on the assessment of the degree of fault of the perpetrator and the degree of social harm of the offence. ${ }^{37}$ Asp notes a similar correlation in relation to the condition of proportionality in the strict sense (according to which the measure must be commensurate with the adverse effects or restrictions imposed), however, a fundamental difference is emphasized here, namely that the principle of potential proportionality concerns negative results that could arise in the future as a result of illegal conduct, while the retrospective concept makes it possible to assess the proportionality of the violation only in the context of an act that has already been committed..$^{38}$

Although the above arguments cannot be denied, this does not mean that both concepts of proportionality have one cohesive element in the form of the commensurability of an adverse effect. It should be stressed that in both cases the compliance with the requirement of proportionality in the strict sense is assessed from two completely different perspectives. Moreover, the principle of proportionality that is applicable in criminal law contains additional restrictions that affect the scope of its application. ${ }^{39}$ This primarily concerns the principle of the individualization of penalties and punitive measures, which consists in adapting them to the individual characteristics and personal circumstances of the perpetrator and the opportunities and prospects for preventive and educational influence on the offender. This principle also implies that the circumstances affecting the penalty are taken into account only in relation to the person to whom they apply (see Article 55 of the PCC). The severity of the penalty is therefore dependent not only on the adverse effects of committing a particular offence, but also on the degree of fault of the individual offender.

\section{The principle of proportionality and European criminal law}

The next issue to be addressed is the definition of the extent to which the principle of proportionality affects the development of European criminal law, primarily with regard to the principle of retrospective proportionality. There is no doubt that the direct transfer of the interpretation of the principle, created on the basis of administrative law, to the area of criminal law is not possible.

37 For more on the subject, see P. Asp, op. cit., p. 6 et seq.

38 Ibidem, p. 7 et seq.

39 For more details on this subject, see ibidem, p. 8 et seq. 
Based on the concept of retrospective proportionality, the starting point is, however, a distinction between two of its models. ${ }^{40}$ The first one, known as ordinal proportionality, ${ }^{41}$ refers to the relative threat of penalty. Its essence is that the perpetrator who committed the crime is sentenced to a punishment commensurate with the degree of culpability and the gravity of the offence committed. However, it should be emphasized that, according to this concept, proportionality is assessed within a particular legal order. The relativity of punishment for a perpetrator means that the punishment must fall within the statutory penalty envisaged for the type of offence which corresponds to a catalogue of penal sanctions applicable in a particular legal system and the rules for meting out penalties by a court. This model of proportionality is therefore intended to indicate that retrospective proportionality does not only serve to determine the limits of permissible punishment for a given type of crime in a particular criminal law system, but also determines the type and level of penalty imposed for an offence committed by a particular offender.

The second model of retrospective proportionality, known as cardinal proportionality, ${ }^{42}$ concerns the correlation between the gravity of the act committed and the upper limit of the statutory penalty for its commitment. It therefore determines what maximum penalty will be commensurate with the type of offence. In practice, this approach to retrospective proportionality should be applied by national courts and the ECJ in determining whether or not the penalty laid down in the EU regulations is commensurate with the gravity of the offence.

\section{Article 49 § 3 of the Charter of Fundamental Rights and the principle of proportionality}

Looking for the normative basis of the principle in question in regulations that are relevant from the perspective of the regulation of European criminal law, attention should be paid to the aforementioned Article 49 of the Charter of Fundamental Rights, which states in $\S 3$ "that the severity of penalties must not be disproportionate to the criminal offence." Referring the above to the observations made in the context of defining the semantic scope of the retrospective proportionality principle, one should consider to which of the presented models of the principle this regulation applies.

Given the fact that the first of the discussed concepts of retrospective proportionality refers to the assessment of proportionality in the light of principles in a particular legal system, applying it on the ground of EU legislation, and therefore in a situation where

40 See ibidem, p. 9 et seq.; A. von Hirsch, Past or future crimes: deservedness and dangerousness in the sentencing of criminals, Manchester 1985, p. 38 et seq.

41 P. Asp, op. cit., p. 9.

42 Ibidem, p. 10; A. von Hirsch, op. cit., p. 43. 
there is no single coherent legal system, but rather the many legal systems of Member States which contain separate and often very different regulations, specifying a catalogue of penalties and rules for sentencing (and thus pursuing their separate national concept of ordinary proportionality), does not seem to be justified. This is further supported by the fact that EU law does not contain provisions defining a catalogue of penalties for criminal offences of a particular type that are uniformly applicable in all Member States and which could serve as a benchmark in the examination of compliance with the principle. Certain secondary legislation acts (i.e. essentially directives, and in the pre-Lisbon legal framework, also the third-pillar framework decisions) contain provisions setting a minimum level for maximum penalties for committing crimes that exhaust strictly defined constitutive elements, however, this "solely" means that Member States are obliged to incorporate into their national legal systems a minimum standard laid down in European regulations. However, this minimum standard covers not only the obligation to combat certain pathologies by means of criminal law instruments, but also the need to take into account in the national legislation a certain minimum threshold of the upper limit of penalty ${ }^{43}$. It must be noted, however, that these EU minimum standards often do not coincide with what was previously envisaged in the national penal provisions of individual states. In such situations, these states are obliged to take these standards into account and adapt their legal regulations to them. ${ }^{44}$ This harmonisation of criminal law does not mean, however, that in this way a coherent catalogue of penalties and a system of sentencing will be established that will apply in all the Member States.

The arguments presented thus prove that the provision of Article $49 \S 3 \mathrm{ChFR}$ EU does not refer to the first model of retrospective proportionality. It should therefore be assumed that it is linked to the cardinal proportionality model. And that means, in turn, that the role of this regulation is solely to set criteria for determining what the maximum penalty must be for committing an offence of a particular type, so that the severity of that penalty is commensurate with the gravity of the act committed. This circumstance entails that the regulation in question for European criminal law is of relatively small

43 See e.g. Article 2 of the Council Framework Decision 2001/500/JHA of 26 July 2001 on money laundering, the identification, tracing, freezing, seizing and confiscation of instrumentalities and proceeds of crime (Official Journal L 182/1 of 5 July 2001); Article $5 \S 3$ of the Council Framework Decision 2002/475/JHA of 13 June 2002 on combating terrorism (Official Journal L 164/3 of 22 June 2002); Article 4 § 2 of the Council Framework Decision 2003/568/JHA of 22 July 2003 on combating corruption in the private sector (Official Journal L 192/54 of 31 July 2003); Article 4 § 1-4 of the Council Framework Decision 2004/757/JHA of 25 Oct. 2004 laying down minimum provisions on the constituent elements of criminal acts and penalties in the field of drug trafficking (Official Journal L 335/8 of 11 November 2004).

44 See also U. Scheffler, Standardy minimalne Rady Europy versus standardy minimalne Rady Unii Europejskiej, in Europeizacja prawa karnego w Polsce $i$ w Niemczech - podstawy konstytucyjnoprawne, ed. A.J. Szwarc, J.C. Joerden, Poznań 2007, p. 106. 
significance, ${ }^{45}$ and the retrospective proportionality principle, laid down in Article 49 $\S \S 3 \mathrm{ChFR} \mathrm{EU}$, sets only a general framework for the actions of the EU legislator in the area of criminal law. ${ }^{46}$ Nevertheless, it should be noted that, due to the ChFR EU status ${ }^{47}$ individuals can rely on it directly if they consider that punishment imposed on them is disproportionately severe to the act they committed.

\section{EU regulations governing police and judicial cooperation in criminal matters and the principle of proportionality}

More attention should be paid to the analysis of legislative actions taken under one of the EU's policies, i.e. police and judicial cooperation in criminal matters, which has been 'communitarised' under the Treaty of Lisbon. However, before the EU's three pillar structure was abolished, the European Union (since the Treaty of Amsterdam entered into force) increasingly often set, by means of secondary legislation instruments (formerly in particular framework decisions and currently directives), specific requirements (known as minimum standards) for Member States, concerning the constituent elements of criminal offences and penalties for their commitment [see ex Article 31(1)(e) TEU; de lege lata Article $83 \S 1 \mathrm{TFEU}] .{ }^{48}$ The justification for such a state of affairs can be seen in the (disputed) assumption that combating cross-border crime also requires a cross-border response. ${ }^{49}$ In the context of European criminal law, the principle of pro-

45 The doctrine also suggests that the principle of proportionality should be interpreted strictly in line with Article 49 of the ChFR EU, i.e. only in the context of those minimum maximum penalties provided for by EU law, and thus make these minimum standards an element of the classification of the different types of offences subject to harmonization; or to interpret it as a principle functioning only in relation to establishing the relationship of EU law with the rules laid down by the national law of a particular Member State. This limited understanding of this regulation does not, however, deserve recognition; critically also see P. Asp, op. cit., p. 11 et seq.

46 It should however be noted that some representatives of the doctrine advocate the application in this area of the concept of potential proportionality which mainly functions in administrative law; see. e.g. P. Asp, op. cit., p. 12 et seq.

47 Let us recall that the Treaty of Lisbon did not incorporate the provisions of the ChFR EU as one of its parts, although under Article 6 of the new TEU - taking into account its objections the ChFR EU has the same legal force as the Treaties, which means - with the entry into force of the LT - the provisions of the Charter of Fundamental Rights will be the primary law of the Union. Cf. J. Barcz, Przewodnik po Traktacie z Lizbony. Traktaty stanowiace Unię Europejska, Warszawa 2008, p. 59 et seq.; A. Frąckowiak-Adamska, Zasada proporcjonalności..., op. cit., p. 90 et seq.

48 See also U. Scheffler, op. cit., p. 104 et seq.

49 As a counter argument, it could be pointed out that the approximation (harmonisation) of Member States' criminal laws as part of judicial cooperation in criminal matters constitutes a threat to the sovereignty and independence of the criminal law systems of individual states, traditionally recognized as the bastions of national sovereignty. Critically, see also J. Piskorski, Subsidiaritätsprinzip im Gemeinschaftsrecht als Voraussetzung für die Kriminalisierung, in 
portionality should, therefore, be referred not only to the issue of determining the scope of the European Union's legislative powers, but also to the scope of permissible criminalisation and penalisation and, above all, the admissible limits of criminal sanctions. In the acts of EU secondary legislation there is a repeatedly expressed requirement ${ }^{50}$ that penalties for committing specific crimes should be dissuasive, effective and commensurate. ${ }^{51}$ It would seem that such an approach to the condition of the proportionality of penalties implies the prohibition of excessive interference with individual rights, and can therefore be interpreted as an emanation of human rights and fundamental freedoms. In the doctrine (mainly German), however, there are many different views. ${ }^{52}$ In this context, it is worth noting in particular the study by Gröblinghoff, who attempted to make a clear distinction between these concepts by assuming that "deterrence" should be understood as potential offenders refraining from infringement due to fear of punishment (negative

Vergleichende Strafrechtswissenschaft. Festschrift für Andrzej J. Szwarc zum 70. Geburtstag, ed. J. C. Joerden, U. Scheffler, A. Sinn, G. Wolf, Berlin 2009, p. 75 and references therein.

50 See e.g. Article $6 \S 1$ of the Council Framework Decision 2000/383/JHA of 29 May 2000 on greater security by criminal penalties and other sanctions against counterfeiting in connection with the introduction of the Euro (Official Journal L 329/3 of 4 December 2001); Article 5 § 1 of the Council Framework Decision 2002/475/JHA of 13 June 2002 on combating terrorism (Official Journal L 164/3 of 22 June 2002); Article $5 \S 1$ of the Council Framework Decision 2003/80/JHA of 27 January 2003 on protection of the environment through criminal law (Official Journal L 29/55 of 5 February 2003); Article $4 \S 1$ of the Council Framework Decision 2003/568/JHA of 22 July 2003 on combating corruption in the private sector (Official Journal L 192/54 of 31 July 2003); Article 58 § 1 of the Directive of the European Parliament and of the Council 2015/849 of 5 May 2015 on the prevention of the use of the financial system for the purposes of money laundering or terrorist financing (Official Journal of the European Union of 5 June 2015, L 141, p. 73 et seq.).

51 The concept of requirements, however, was created by the Council, which had already applied them in joint actions which were the predecessors of the framework decisions under the Maastricht Treaty (see e.g. Title II, Section B, point B, Joint Action 97/154 / JHA of 24 February 1997 on combating trafficking in human beings and sexual exploitation of children, Official Journal L 63/2 of 4 March 1997]; Article 2 § 1 and Article 3 of the Joint Action 98/733/JHA of 21 December 1998 on making it a criminal offence to participate in a criminal organisation in the Member States of the European Union (Official Journal L 351/1 of 29 December 1998), but derive from ECJ jurisprudence, where it first appeared in the judgement on "Greek maize": Komisja v. Grecja, 68/88, p. 2965. They can also be found in Article $2 \S 2$ of the Convention of 26 July 1995 on the protection of the financial interests of the European Communities (Official Journal C 316/49 of 27 November 1995). See also T. Weigend, Mindestanforderungen an ein europaweit geltendes harmonisiertes Strafrecht, in Strafrecht und Kriminalität in Europa, ed. F. Zieschang, E. Hilgendorf, K. Laubenthal, Baden-Baden 2003, p. 59; K. Tiedemann, Gegenwart und Zukunft des Europäischen Strafrechts, ZStW 2004, no. 116, p. 953.

52 See, e.g., T. Weigend, op. cit., p. 79: "Within the meaning of the ECJ jurisdiction, the substantive distinction between the three prerequisites, 'effective, proportionate and dissuasive' is almost impossible.” And also S. Gröblinghoff, Die Verpflichtungen des deutschen Strafgesetzgebers zum Schutze der Interessen der Europäischen Gemeinschaften, Heidelberg 1996, p. 37: "each of these constituent elements is undefined." 
general prevention); effectiveness means that the sanction must be adequate to stop the individual from further infringements (individual prevention), and to deter the general public, by introducing commensurate sanctioning standards and their adequate application, to voluntarily adhere to these standards (positive general prevention); and finally, proportionality covers the gravity of the infringement. ${ }^{53}$ Satzger is also of a similar opinion, treating effectiveness and deterrence as a homogeneous criterion and assuming that proportionality refers to at least the necessary threat of punishment imposed in connection with committing an offence. ${ }^{54}$

The conclusion should therefore be that the criterion of proportionality, as it appears in the regulations of the EU secondary legislation, does not serve to set a minimum level of maximum criminal penalty permissible under a national legal system, but rather to prohibit disregard for violation of EU regulations by imposing disproportionately low sanctions. It may, therefore, be accepted that it is rather intended to establish "minimum sanctions" aimed at excluding ineffective and non-dissuasive penalties. ${ }^{55}$

In conclusion, it should be noted, however, that the assessment of the appropriateness of adopting EU minimum rules for criminal sanctions in the light of compliance with the principle of proportionality seems to be important. Much more problematic is the presentation of convincing arguments, advocating the need for uniform EU-wide measures, where each Member State has its own national catalogue of criminal sanctioning, a system of penalties and anti-crime instruments. It seems that, in the light of the requirement to comply with the principle of proportionality, it would be easier to establish a catalogue of prohibited acts that would be subject to joint combat in the EU area, as well as penalties for committing them, than to harmonise the criminal law institutions existing in the Member States.

\section{Conclusions}

As a summary of these considerations, two main conclusions can be drawn. First, the application of the principle of proportionality in the law of the European Union is horizontal, i.e. at all levels of legislation and, in practice, it permeates the EU legal system. ${ }^{56}$ In this context, the principle of proportionality is primarily a judicial control instrument - the role of the ECJ is dominant here, although the role of national courts cannot be overlooked. This control is performed not only in relation to legislative actions taken by the EU institutions, but also in relation to different kinds of measures that are imposed on the basis of the regulations of EU law, including sanctions. This is because

53 S. Gröblinghoff, op. cit., p. 25 et seq.

54 H. Satzger, Die Europäisierung des Strafrechts, Köln 2001, pp. 368, 372.

55 See also U. Scheffler, op. cit., p. 109; T. Weigend, op. cit., p. 79.

56 J. Maliszewska-Nienartowicz, Stosowanie..., op. cit., p. 16 and references therein. 
the Court of Justice is of the opinion that the penalty should be proportionate to the infringement. ${ }^{57}$ By applying the control mechanism described above, the individual interest is related in this case to the sanction imposed, whereas the public interest (EU) is related to the guarantee of the application of European Union law. In this case, the ECJ will investigate whether the sanction is proportionate - i.e. whether it contributes to the achievement of the Treaty objective and whether the entity on which it has been imposed does not suffer undue burdens. ${ }^{58}$ As regards the determination of compliance with the principle of proportionality of the sanctions imposed by the EU institutions or by Member States for infringing EU law, the criterion of proportionality is applied in the strict sense. So there is a kind of "balancing of interests," i.e. the effect of deterring from acting compared to the cost of punishing the perpetrator. ${ }^{59}$

On the other hand, the application of the principle of proportionality in the area of European criminal law requires above all an answer to the question of the legitimacy of extending the powers of the EU to the field of criminal law and the potential scope of permissible intervention of the EU legislator in the freedom and rights of the individual. As shown above, this principle is developing in two ways: in the ECJ case law and in EU secondary legislation, and its subject is a mechanism for the determination of penalties, the severity of which must be proportionate to the gravity of the offence. Bearing in mind that not all Member States formulate their national system of penalties and the rules of sentencing based on the principle of proportionality, and that the national criminal law regimes of the Member States may differ significantly in terms of the degree of repression, instruments of EU law defining a minimum standard somehow automatically impose an obligation on states with less repressive punishment to adapt their laws to those of more repressive states. In my opinion, this circumstance stems from the unreasonable assumption that the differences between Member States regarding the degree of repression of domestic criminal law systems constitute a problem that can only be solved by adopting harmonising measures consisting in setting a minimum standard at the level foreseen in states with more repressive law. The assumption that increased repression of criminal law provisions contributes to the effectiveness of combating crime is highly controversial. Even among the Member States of the European Union with high crime-fighting statistics, it is possible to distinguish those whose criminal law is rather repressive from those whose criminal law is more liberal. It is not an easy task to deter-

57 See the ECJ judgement in Atalanta Amsterdam BV v. Produktschap voor Vee Ne Vlees, 240/78, p. 2137.

58 J.Maliszewska-Nienartowicz, Sqdowe..., op. cit., p. 12; eadem, Zasada proporcjonalności w prawie Wspólnot Europejskich-kryteria..., op. cit., p. 265 et seq.; eadem, Zasada proporcjonalności w prawie Wspólnot Europejskich, op. cit., p. 96 et seq.

59 For more details on this subject: J. Maliszewska-Nienartowicz, Sadowe..., op. cit., p. 12; eadem, Zasada proporcjonalności w prawie Wspólnot Europejskich-kryteria..., op. cit., p. 264 et seq.; eadem, Zasada proporcjonalności w prawie Wspólnot Europejskich, op. cit., p. 95 et seq. 
mine the correct correlation between the degree of repression of criminal law and actions taken on its basis that are intended to effectively prevent and combat specific pathologies. ${ }^{60}$ The same difficulties arise in the process of establishing a minimum framework for the threat of punishment for committing a crime of a particular type. For this reason, the legitimacy of the EU legislator setting increasingly repressive minimum standards that specify a maximum penalty for committing a particular crime seems to raise reasonable doubts. Especially since the analysis of European legislation that provides for such standards often leads to the conclusion that the principle of proportionality has not been taken into account in the process of its creation.

\section{Literature}

Asp P., Two notions of Proportionality, in Materials from the $22^{\text {nd }}$ IVR Word Congress, www. crimpol.eu/?p=200 [access: 12.02.2017].

Barcz J., Przewodnik po Traktacie z Lizbony. Traktaty stanowiace Unie Europejskg, Warszawa 2008.

Emiliou N., The Principle of Proportionality in European Law, London - The Hague Boston 1996.

Frąckowiak-Adamska A., Podwójne zasady badania proporcjonalności przez Trybunat Sprawiedliwości, in Zasady ogólne prawa wspólnotowego, ed. C. Mik, Toruń 2007.

Frąckowiak-Adamska A., Zasada proporcjonalności jako grwarancja swobód rynku wewnętrznego Wspólnoty Europejskiej, Warszawa 2009.

Gröblinghoff S., Die Verpflichtungen des deutschen Strafgesetzgebers zum Schutze der Interessen der Europäischen Gemeinschaften, Heidelberg 1996.

Hirsch A. von, Past or future crimes: deservedness and dangerousness in the sentencing of criminals, Manchester 1985.

Jareborg N., Criminalization as Last Resort (Ultima Ratio), "Ohio State Journal of Criminal Law" 2004, no. 2.

Królikowski M., Sprawiedliwość karania w spoteczeństwach liberalnych: zasada proporcjonalności, Warszawa 2005.

Maliszewska-Nienartowicz J., Rozwój zasady proporcjonalności w europejskim prawie wspólnotowym, "Studia Europejskie"2006, no.1.

Maliszewska-Nienartowicz J., Sądowe stosowanie zasady proporcjonalności, "Europejski Przegląd Sądowy”2009, no. 1.

Maliszewska-Nienartowicz J., Zasada proporcjonalności w prawie Wspólnot Europejskich, Toruń 2007.

60 Cf. P. Asp, op. cit., p. 13. 
Maliszewska-Nienartowicz J., Zasada proporcjonalności w prawie Wspólnot Europejskich kryteria i zakres kontroli dokonywanej przez Trybunat Sprawiedliwości, in Zasady ogólne prawa wspólnotowego, ed. C. Mik, Torun 2007.

Milczarek D., Subsydiarność-próba bilansu, in Subsydiarnośc, ed. D. Milczarek, Warszawa 1998.

Piskorski J., Subsidiaritätsprinzip im Gemeinschaftsrecht als Vorraussetzung für die Kriminalisierung, in Vergleichende Strafrechtswissenschaft. Frankfurter Festschrift für Andrzej J. Szwarc zum 70. Geburtstag, ed. J.C. Joerden, U. Scheffler, A. Sinn, G. Wolf, Berlin 2009.

Piskorski J., Legitymizacja prawa karnego Unii Europejskiej, Poznań 2013.

Rivers J., Proportionality and discretion in international and European law, in Transnational Constitutionalism. International and European Models, ed. N. Tsagourias, Cambridge 2009.

Satzger H., Die Europäisierung des Strafrechts, Köln 2001.

Scheffler U., Standardy minimalne Rady Europy versus standardy minimalne Rady Unii Europejskiej, in Europeizacja prawa karnego w Polsce i w Niemczech - podstawy konstytucyjnoprawne, ed. A.J. Szwarc, J. C. Joerden, Poznań 2007.

Szpringer W., Subsydiarnośc jako zasada ustrojowa w państwie federalnym - członku Unii Europejskiej (na przyktadzie RFN), in Subsydiarnośc, ed. D. Milczarek, Warszawa 1998.

Szwarc-Kuczer M., Kompetencje Unii Europejskiej w dziedzinie harmonizacji prawa karnego materialnego, Warszawa 2011.

Tiedemann K., Gegenwart und Zukunft des Europäischen Strafrechts, ZStW 2004, no. 116. Weigend T., Mindestanforderungen an ein europaweit geltendes harmonisiertes Strafrecht, in Strafrecht und Kriminalität in Europa, ed. F. Zieschang, E. Hilgendorf, K. Laubenthal, Baden-Baden 2003.

Witkowska M., Zasady funkcjonowania Unii Europejskiej, Warszawa 2008.

Wyrozumska A., Państwa cztonkowskie a Unia Europejska, in Prawo Unii Europejskiej. Zagadnienia systemowe. Prawo materialne i polityki, ed. J. Barcz, Warszawa 2006.

\section{SUMMARY \\ The Principle of Proportionality in European Union Law as a Prerequisite for Penalization}

The paper analysis the principle of proportionality, which is widely applied in the EU legal order and is therefore one of the fundamental principles of the system of the European Union. It is one of the legal principles that govern decision-making processes and common strategic objectives, and which are applicable when establishing European Union legislation and transposing it into national law, including in the area of criminal 
300 | Adam Mickiewicz University Law Review

law, although the current analyses do not often focus on discussing this aspect. Due to its complexity and significance for the processes of establishing and applying the law, the principle of proportionality requires detailed and separate discussion, especially in the context of European criminal law.

Keywords: European criminal law, principle if proportionality in the EU, penalization

Joanna DŁugosz, Adam Mickiewicz University Poznań, Faculty of Law and Administration, Al. Niepodległości 53, 61-714 Poznań, Republic of Poland, e-mail: jdlugosz@ amu.edu.pl. 